\title{
The $\beta$-Lactamase Secreted by the Antarctic Psychrophile Psychrobacter immobilis A8
}

\author{
GEORGES FELLER,* PIERRE SONNET, AND CHARLES GERDAY \\ Laboratory of Biochemistry, Institute of Chemistry, Université de Liège, B-4000 Liège-Sart Tilman, Belgium
}

Received 6 July 1995/Accepted 27 September 1995

\begin{abstract}
A class $C$-lactamase has been purified from the culture supernatant of the antarctic psychrophile Psychrobacter immobilis A8. This psychrophilic $\beta$-lactamase displays a low level of thermal stability and a low optimal temperature of activity. In contrast to other cold-adapted enzymes, its level of specific activity is not higher than that of mesophilic class $\mathrm{C} \beta$-lactamases.
\end{abstract}

Psychrophilic microorganisms have the largest distribution on earth if one considers the extent of area where temperature remains permanently below $10^{\circ} \mathrm{C}$ (deep-sea waters, mountains, and polar regions). In spite of their diversity and abundance, the analysis of the physiological and biochemical adaptations of cold-adapted microorganisms is still fragmented $(2,11,13$, 16, 19). Nevertheless, psychrophilic strains and particularly their enzymes, which are able to perform catalysis efficiently at low temperatures, have been proposed for a number of applications in biotechnology $(7,11,20)$.

In the context of the study of protein adaptation to low temperatures, we have selected an antarctic bacterial strain collected in an environment ranging in temperature from -20 to $+2^{\circ} \mathrm{C}$ that produces a $\beta$-lactamase. Bacterial $\beta$-lactamases (EC 3.5.2.6) hydrolyze the amide bond of the $\beta$-lactam ring of penicillin-derived antibiotics, yielding biologically inactive compounds. Because of their critical role in bacterial antibiotic resistance, the substrate specificities and the action mechanisms of $\beta$-lactamases have been widely studied. Several primary structures are known, and the three-dimensional structures of some $\beta$-lactamases from gram-negative and gram-positive bacteria have been determined to high resolution $(4,10,14,18)$. Therefore, a detailed comparison of the functional and structural properties of the extremophilic enzyme is possible. $\beta$-Lactamases are commonly classified into four groups $(1,14)$. Class A (penicillinases), class $\mathrm{C}$ (cephalosporinases), and class $\mathrm{D}$ enzymes belong to the active-serine enzyme superfamily and differ in their primary structures, whereas class B $\beta$-lactamases rely on the presence of a $\mathrm{Zn}^{2+}$ ion in their active site.

Strain characterization. Psychrobacter immobilis A8 was collected near the antarctic station Dumont d'Urville $\left(66^{\circ} 40^{\prime} \mathrm{S}\right.$, $140^{\circ} 01^{\prime} \mathrm{E}$ ) on frozen organic debris. This gram-negative strain was identified on the basis of its metabolic profile, which was determined by the analytical profile index API 20B and the API 20NE system, by the sodium dodecyl sulfate-polyacrylamide gel electrophoresis (SDS-PAGE) pattern of soluble cellular proteins, and by total cellular fatty acid fingerprints (Belgian Coordinated Collections of Microorganisms, Ghent, Belgium). The upper cardinal temperature of growth for $P$. immobilis was $25^{\circ} \mathrm{C}$. However, optimal growth and $\beta$-lactamase production were found below $10^{\circ} \mathrm{C}$. The generation time of the strain at $4^{\circ} \mathrm{C}$ was $6 \mathrm{~h} ; \beta$-lactamase secretion into the culture supernatant followed bacterial growth, and less than $15 \%$ of

\footnotetext{
* Corresponding author. Mailing address: Laboratory of Biochemistry, Institute of Chemistry B6, Université de Liège, B-4000 Liège-Sart Tilman, Belgium. Phone: 32-41-66 33 43. Fax: 32-41-66 3364.
}

the total activity remained cell associated at the early stationary phase.

$\boldsymbol{\beta}$-Lactamase purification. The strain was cultivated at $4^{\circ} \mathrm{C}$ for 3 days in 3 liters of medium containing $16 \mathrm{~g}$ of Bacto Tryptone per liter, $5 \mathrm{~g}$ of yeast extract per liter, and $2.5 \mathrm{~g}$ of $\mathrm{K}_{2} \mathrm{HPO}_{4}(\mathrm{pH} 7.6)$ per liter. After centrifugation at 23,000 $\times g$, the culture supernatant was adjusted to $0.02 \% \mathrm{NaN}_{3}$, concentrated to $450 \mathrm{ml}$, and diafiltrated against $15 \mathrm{mM} \mathrm{HCl}$-piperazine, $\mathrm{pH}$ 6.5, using a Minitan tangential flow ultrafiltration unit (Millipore) fitted with PTGC membranes (with a $10-\mathrm{kDa}$ retention limit). The sample was loaded on a DEAE-cellulose column $(2.6$ by $25 \mathrm{~cm})$ equilibrated in the above-mentioned buffer and eluted with a $\mathrm{NaCl}$ linear gradient $(220 \mathrm{ml}$ and 220 $\mathrm{ml}, 0 \mathrm{M}$ and $0.1 \mathrm{M} \mathrm{NaCl}$ ) applied after a $100-\mathrm{ml}$ buffer elution. Fractions containing $\beta$-lactamase activity were concentrated to $10 \mathrm{ml}$ and applied onto a Sephacryl S-200 column (2.6 by 60 $\mathrm{cm}$ ) eluted with $25 \mathrm{mM}$ Tris- $\mathrm{HCl}, \mathrm{pH}$ 8.0. Active fractions were adjusted to $0.5 \mathrm{M} \mathrm{NaCl}$ and concentrated to $10 \mathrm{ml}$. The sample was then loaded on a phenylboronic acid-agarose column (1.6 by $20 \mathrm{~cm}$ ) (3) eluted with $25 \mathrm{mM}$ Tris-HCl- $0.5 \mathrm{M} \mathrm{NaCl}(\mathrm{pH}$ 8.0). In order to elute the enzyme in a sharp peak, $125 \mathrm{mM}$ $\mathrm{K}_{2} \mathrm{~B}_{4} \mathrm{O}_{7} \cdot 4 \mathrm{H}_{2} \mathrm{O}$ was added to the irrigating buffer after a $30-\mathrm{ml}$ elution. For further experiments, the purified enzyme was concentrated on a PTGC ultrafiltration membrane and conditioned in $25 \mathrm{mM}$ Tris-HCl, $\mathrm{pH}$ 8.0, by gel filtration on a PD10 column (Pharmacia Biotech Inc.). A standard assay of $\beta$-lactamase activity was carried out at $25^{\circ} \mathrm{C}$ with $300 \mu \mathrm{M}$ nitrocefin (Glaxo Group Research, Greenford, Middlesex, United Kingdom) as the substrate in $50 \mathrm{mM}$ phosphate buffer, $\mathrm{pH}$ 7.0. Levels of activity towards the chromogenic substrate were recorded by a thermostated Uvicon 860 spectrophotometer (Kontron) and were calculated with an $A_{482}$ of $15,000 \mathrm{M}^{-1}$ $\mathrm{cm}^{-1}$ (17). Protein concentrations were determined with Coomassie protein reagent (Pierce). Table 1 summarizes the purification steps used to obtain $P$. immobilis $\beta$-lactamase. About $20 \mu \mathrm{g}$ of $\beta$-lactamase per liter of culture was recovered in a fairly pure state as judged by SDS-PAGE (Fig. 1). According to the purification yield, the $\beta$-lactamase secretion in the supernatant was estimated to be $100 \mu \mathrm{g} / \mathrm{liter}$.

Characterization of $\boldsymbol{P}$. immobilis $\boldsymbol{\beta}$-lactamase. The apparent molecular mass of the $\beta$-lactamase was found to be $41,000 \mathrm{Da}$ by SDS-PAGE, and its pI was 5.3 as indicated by isoelectric focusing; both tests were carried out as described by the supplier of the electrophoretic equipment (Hoefer Scientific Instruments). The $\mathrm{N}$-terminal amino acid sequence of the native enzyme was determined with a pulsed-liquid-phase protein sequenator (model 477A; Applied Biosystems) equipped with an on-line $120 \mathrm{~A}$ phenylthiohydantoin analyzer. The alignment 
TABLE 1. Purification of extracellular $\beta$-lactamase from P. immobilis A8

\begin{tabular}{lccccc}
\hline \multicolumn{1}{c}{ Purification step } & Vol $(\mathrm{ml})$ & Protein $(\mathrm{mg})$ & $\begin{array}{c}\text { Sp act } \\
\left(\mu \mathrm{mol} \cdot \mathrm{min}^{-1} \cdot \mathrm{mg}^{-1}\right)\end{array}$ & $\begin{array}{c}\text { Yield }(\%) \\
(\text { fold })\end{array}$ \\
\hline Culture supernatant & 2,600 & 514 & 0.6 & 100 \\
Diafiltration & 450 & 256 & 0.9 & 73 & 1.4 \\
DEAE-cellulose & 68 & 9.2 & 17.5 & 50 & 28 \\
Sephacryl S-200 & 40 & 1.3 & 148 & 38 & 218 \\
Phenylboronic acid-agarose & 25 & 0.06 & 1,053 & 19 \\
\hline
\end{tabular}

of the first nine amino acids of $P$. immobilis $\beta$-lactamase with the N-terminal sequence of the class $C \beta$-lactamase from Pseudomonas aeruginosa (15) shows three conserved positions, two similarities, and a possible inversion of the second and third positions; no N-terminal homology was found with other class $\mathrm{C} \beta$-lactamases:

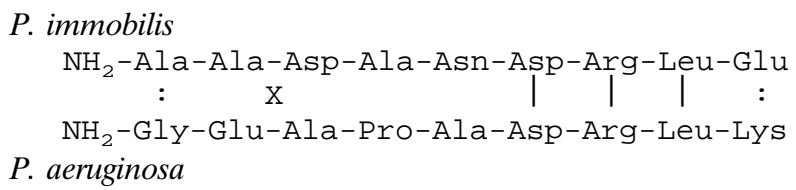

The $\mathrm{pH}$ stability of $P$. immobilis $\beta$-lactamase was determined after a 25 -h sequential incubation at $4^{\circ} \mathrm{C}$ in McIlvaine's citric acid-phosphate buffer ( $\mathrm{pH} 3.0$ to 5.0), in $15 \mathrm{mM} \mathrm{HCl}$-piperazine (pH 5.5 to 6.5$)$, in $75 \mathrm{mM}$ imidazole (pH 7.0), in $75 \mathrm{mM}$ Tris ( $\mathrm{pH} 8.0$ to 9.0 ), and in $75 \mathrm{mM}$ 3-(cyclohexylamino)-1propanesulfonic acid (CAPS; $\mathrm{pH} 10.0$ to 11.0). The enzyme was stable over a wide $\mathrm{pH}$ range (from $\mathrm{pH} 4$ to 10) with an optimum $\mathrm{pH}$ value near neutrality. The activity of $P$. immobilis $\beta$-lactamase was unaffected by $5 \mathrm{mM}$ EDTA, indicating that $P$. immobilis $\beta$-lactamase does not pertain to the class $\mathrm{B}$ metalloenzymes. By contrast, incubation at $4^{\circ} \mathrm{C}$ in the presence of 1 and $100 \mu \mathrm{M}$ oxacillin led to 50 and $100 \%$ inhibition of the activity towards nitrocefin, respectively. Oxacillin inhibition is typical of class A and C $\beta$-lactamases (9). Activities towards cephalosporins (nitrocefin and cephalexin) and penicillins (benzylpenicillin and ampicillin) have been recorded at saturating substrate concentrations (8). The corresponding catalytic constant values are given in Table 2 and are compared with the range of values recorded for mesophilic class $C \beta$-lac-

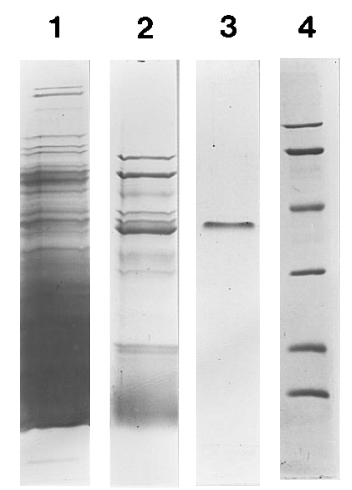

FIG. 1. SDS-polyacrylamide gel stained with Coomassie brilliant blue R-250 showing (lane 1) the crude $P$. immobilis culture supernatant, (lane 2) the fraction before phenylboronic acid-agarose chromatography, (lane 3 ) the purified $\beta$-lactamase ( $3 \mu \mathrm{g}$ was loaded), and (lane 4 ) protein standards (from the top: phosphorylase $b, 97.4 \mathrm{kDa}$; bovine serum albumin, $66.2 \mathrm{kDa}$; ovalbumin, $42.7 \mathrm{kDa}$; carbonic anhydrase, $31 \mathrm{kDa}$; soybean trypsin inhibitor, $21.5 \mathrm{kDa}$; and lysozyme, $14.4 \mathrm{kDa})$. tamases $(8,9)$. This substrate specificity clearly relates $P$. immobilis $\beta$-lactamase to cephalosporinases.

Thermodependence and stability. The thermodependence activities of the psychrophilic enzyme and of the class $C \beta$-lactamase from the mesophile Enterobacter cloacae 908R are shown in Fig. 2A. One can observe a shift in the apparent optimal temperatures of activity of the psychrophilic enzyme towards low temperatures (from $770 \mathrm{~s}^{-1}$ at $50^{\circ} \mathrm{C}$ for E. cloacae to $885 \mathrm{~s}^{-1}$ at $35^{\circ} \mathrm{C}$ for $P$. immobilis). However, below $10^{\circ} \mathrm{C}$ both psychrophilic and mesophilic enzymes display similar catalytic constant values. The thermal stability of $\beta$-lactamase activity is illustrated by the denaturation curves at $50^{\circ} \mathrm{C}$ (Fig. 2B). Under these conditions, the activity of the mesophilic enzyme remains unaffected during at least $1 \mathrm{~h}$, whereas the half time of inactivation for the $P$. immobilis enzyme is less than $4 \mathrm{~min}$.

Conclusions. The various structural and kinetic properties of the psychrophilic enzyme relates it to class $C \beta$-lactamases. Pathogenic gram-negative bacteria producing $\beta$-lactamases invariably direct and concentrate the enzyme in the periplasmic space where the penicillin targets are located $(4,10)$. As far as we know, $P$. immobilis A8 is the first example of a gramnegative bacterium producing $\beta$-lactamase in the extracellular medium. $\beta$-Lactamase secretion is possibly a weakly efficient ancestral protective mechanism against bacteriolytic microorganisms producing $\beta$-lactam-derived metabolites.

$P$. immobilis $\beta$-lactamase displays a low optimum temperature of activity and a low level of thermal stability, which are common characteristics of proteins from cold-adapted organisms evolving in a strongly selective, permanently cold environment $(2,12)$. However, the level of specific activity at low temperatures of these enzymes is generally 3 to 10 times higher than that of their mesophilic counterparts; this is the main adaptation of these enzymes to catalysis at low environmental temperatures $(5,6)$. By contrast, the level of activity of $P$. immobilis $\beta$-lactamase below $10^{\circ} \mathrm{C}$ is similar to that of its mesophilic counterpart. It should be noted that $\beta$-lactamase does not belong to a metabolic pathway in which adequate flux has to be maintained at low temperatures; a high level of specific activity is probably not required if the surrounding concentra-

TABLE 2. Catalytic constants for the hydrolysis of some $\beta$-lactam compounds by the psychrophilic $\beta$-lactamase and mesophilic class C $\beta$-lactamases

\begin{tabular}{lcc}
\hline \multirow{2}{*}{ Substrate } & \multicolumn{2}{c}{ Catalytic constant $\left(\mathrm{s}^{-1}\right)$} \\
\cline { 2 - 3 } & $\begin{array}{c}\text { P. immobilis } \\
\beta \text {-lactamase } \\
\left(25^{\circ} \mathrm{C}\right)\end{array}$ & $\begin{array}{c}\text { Mesophilic class C } \\
\beta \text {-lactamases }\end{array}$ \\
\hline Nitrocefin & 720 & $330-1,240$ \\
Cephalexin & 96 & $38-150$ \\
Benzylpenicillin & 10 & $14-76$ \\
Ampicillin & 0.5 & $0.5-6.5$ \\
\hline
\end{tabular}

${ }^{a}$ Data are from references 8 and 9. 


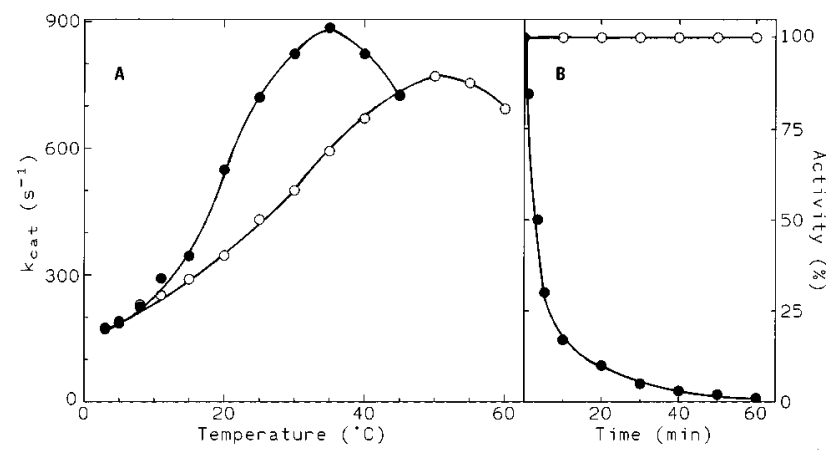

FIG. 2. (A) Effect of assay temperatures on psychrophilic and mesophilic $\beta$-lactamase activity. Levels of nitrocefin hydrolysis of $P$. immobilis $(\mathbf{)})$ and $E$. cloacae $(\bigcirc) \beta$-lactamases were recorded at increasing temperatures. $\mathrm{k}_{\mathrm{cat}}$, catalytic constant. (B) Thermal stability of $\beta$-lactamase activity. P. immobilis $(\mathbf{O})$ and E. cloacae $(\bigcirc)$ enzymes were incubated at $50^{\circ} \mathrm{C}$ in $25 \mathrm{mM}$ Tris- $\mathrm{HCl}-1 \mu \mathrm{g}$ of bovine serum albumin per $\mathrm{ml}(\mathrm{pH} 8.0)$, and residual activities were recorded under standard assay conditions.

tion of $\beta$-lactam antibiotics is low, as expected in the antarctic environment. Alternatively, the psychrophilic enzyme could be highly specific for an unidentified substrate. On the other hand, all class $C \beta$-lactamases from pathogenic mesophilic bacteria studied so far $(8,9)$ have evolved under the strong selective pressure of antibiotics. They are produced in large amounts ( $>1 \mathrm{mg} /$ liter of culture), and they can be regarded as enzymes from a special class of extremophiles having highly optimized kinetic parameters. In this respect, the $\beta$-lactamase from $P$. immobilis is well suited for further analysis of structural factors affecting protein stability.

The Institut Français de la Recherche Polaire is acknowledged for the support and facilities offered at the antarctic station Dumont d'Urville. This work was supported by the research contracts FRFC 2.4526.92 and concerted action ARC 93/98-170.

We thank J. M. Frère for his interest in this work and for a gift of $E$. cloacae $\beta$-lactamase. We acknowledge N. Gerardin-Otthiers and R. Marchand for expert technical assistance.

\section{REFERENCES}

1. Ambler, R. P. 1980. The structure of $\beta$-lactamases. Philos. Trans. R. Soc. Lond. B Biol. Sci. 289:321-331.
2. Arpigny, J. L., G. Feller, S. Davail, S. Genicot, E. Narinx, Z. Zekhnini, and C. Gerday. 1994. Molecular adaptations of enzymes from thermophilic and psychrophilic organisms, p. 269-295. In R. Gilles (ed.), Advances in comparative and environmental physiology, vol. 20. Springer-Verlag, Berlin.

3. Cartwright, S. J., and S. G. Walley. 1984. Purification of $\beta$-lactamases by affinity chromatography on phenylboronic acid-agarose. Biochem. J. 221: 505-512.

4. Coyette, J., M. Nguyen-Distèche, J. Lamotte-Brasseur, B. Joris, E. Fonzé, and J. M. Frère. 1994. Molecular adaptations in resistance to penicillins and other $\beta$-lactam antibiotics, p. 233-267. In R. Gilles (ed.), Advances in comparative and environmental physiology, vol. 20. Springer-Verlag, Berlin.

5. Davail, S., G. Feller, E. Narinx, and C. Gerday. 1994. Cold adaptation of proteins. Purification, characterization and sequence of the heat-labile subtilisin from the antarctic psychrophile Bacillus TA41. J. Biol. Chem. 269: 17448-17453.

6. Feller, G., T. Lonhienne, C. Deroanne, C. Libioulle, J. Van Beeumen, and C. Gerday. 1992. Purification, characterization, and nucleotide sequence of the thermolabile $\alpha$-amylase from the antarctic psychrotroph Alteromonas haloplanctis A23. J. Biol. Chem. 267:5217-5221.

7. Feller, G., E. Narinx, J. L. Arpigny, Z. Zekhnini, J. Swings, and C. Gerday. 1994. Temperature dependence of growth, enzyme secretion and activity of psychrophilic antarctic bacteria. Appl. Microbiol. Biotechnol. 41:477-479.

8. Galleni, M., G. Amicosante, and J. M. Frère. 1988. A survey of the kinetic parameters of class $\mathrm{C} \beta$-lactamases. Cephalosporins and other $\beta$-lactam compounds. Biochem. J. 255:123-129.

9. Galleni, M., and J. M. Frère. 1988. A survey of the kinetic parameters of class C $\beta$-lactamases. Penicillins. Biochem. J. 255:119-122.

10. Ghuysen, J. M. 1991. Serine beta-lactamases and penicillin-binding proteins. Annu. Rev. Microbiol. 45:37-67.

11. Gounot, A. M. 1991. Bacterial life at low temperature: physiological aspects and biotechnological implications. J. Appl. Bacteriol. 71:386-397.

12. Hochachka, P. W., and G. N. Somero. 1984. Biochemical adaptations. Princeton University Press, Princeton, N.J.

13. Innis, W. E. 1975. Interaction of temperature and psychrophilic microorganisms. Annu. Rev. Microbiol. 29:445-465.

14. Lamotte-Brasseur, J., J. Knox, J. A. Kelly, P. Charlier, E. Fonzé, O. Dideberg, and J. M. Frère. 1994. The structures and catalytic mechanisms of active-site serine $\beta$-lactamases. Biotechnol. Genet. Eng. Rev. 12:189-230.

15. Lodge, J. M. S. D. Minchin, L. J. V. Piddock, and S. J. W. Busby. 1990 Cloning, sequencing and analysis of the structural gene and regulatory region of the Pseudomonas aeruginosa chromosomal ampC $\beta$-lactamase. Biochem. J. 272:627-631.

16. Morita, R. Y. 1975. Psychrophilic bacteria. Bacteriol. Rev. 39:144-167.

17. O'Callaghan, C., A. Morris, S. Kirby, and A. Shingler. 1972. Novel method for detection of $\beta$-lactamases by using a chromogenic cephalosporin substrate. Antimicrob. Agents Chemother. 1:283-288.

18. Page, M. I. 1992. The chemistry of $\beta$-lactams. Chapman and Hall, Glasgow, Scotland.

19. Russel, N. J. 1990. Cold adaptation of microorganisms. Philos. Trans. R. Soc. Lond. B Biol. Sci. 326:595-611.

20. Russel, N. J. 1992. Physiology and molecular biology of psychrophilic microorganisms, p. 203-224. In R. A. Herbert and R. J. Sharp (ed.), Molecular biology and biotechnology of extremophiles. Blackie, London. 